\title{
Employee Retention Practices in Hospitality Industry in Nepal: Investigating the Moderating Effect of Management Hierarchy, Age Group and Gender
}

\author{
Arhan Sthapit ${ }^{1}$ and Bikash Shrestha ${ }^{2}$ \\ ${ }^{1,2}$ Faculty of Management, Tribhuvan University, Nepal \\ https://orcid.org/0000-0002-2799-4936
}

\begin{abstract}
Since it is indispensable for organizations to employ and retain quality human resources (HRs) and talents for their effective operation and continuous growth, it is imperative and relevant to investigate into the HR retention practices and strategies. Hence, the paper examines the influence of human resource management practices on employee retention and the moderating effect of management hierarchy, age group and gender on HR retention factors in hospitality industry of Nepal. The study employed a cross-sectional descriptive survey design with a sample of 292 respondents from six out of eight five-star hotels of Nepal stationed in the capital Valley of Kathmandu. Using correlation analysis, Jonckheere-Terpstra test, as well as post hoc and Mann-Whitney U tests, the study discovered that rewards and compensation help retain entry level employees, while employer branding is a strong retention measure for those on higher hierarchies. Likewise, balanced work life and employer branding help retain higher age group employees, while career growth is the strongest and balanced work life the weakest measure to retain male hotel employees in Nepal.
\end{abstract}

Keywords: employee retention, compensation, career growth, balanced work life, employer branding

\section{Introduction}

In the global business environment, employee commitment, productivity and retention issues are emerging as the most critical workforce management challenges (Caplan \& Teese, 1997). As a result of globalisation and liberalisation, competition of labour market has increased and the war for talents has intensified. Today's organisations value their intellectual assets more than their hard assets and physical resources. Due to increasing levels of importance for recognition of the workforce, employee skills, employee knowledge and experiences, recruitment and retention of employees has become a major concern for organisations (Arachchige \& Alan, 2013).

Employment and retention of the new talent has been significant in continuous growth of an organisation. The retention of employees has shown to be significant to the development and the accomplishment of the organisation's goals and objectives, especially in building competitive advantage over other organisations in the phase of increased globalisation (Armstrong, 2001). And, also tourism and hospitality industry has continued to receive rigorous attention of academics, business tycoons and economic analysts because of its growing effect on the economy (Uddin, 
Das, \& Rahman, 2008). The hotel industry is a dynamic service sector where optimal human resource management is required to ensure professionalism and efficiency in service delivery (Hanzaee \& Mirvaisi, 2011). Ogbonna and Lloyd (2002) recognise employee retention as vital for the hospitality sector, as it employs more people than any other industry within the private sector, both domestically and globally. Oster (2004) posits the process of retention as a gain for the organisation, as the cost of turnover increases a firm's expenditure and reduces profits. However, huge problems exist in attracting and retaining a skilled workforce in this industry.

\section{Statement of Problem}

High employee turnover is one of the major problems (Fladetta, Fasone, \& Provenzano 2013) and a continuous challenge for the hospitality industry (Brown, Thomas, \& Bosselman, 2015). The value of employee retention in the global hotel industry is irrefutable, as this sector has experienced problems with retaining their employees over a period of time (Farrell, 2001). Low retention rates in hotel industry has affected the ability to deliver a consistent brand experience, harming business; and the fact that not enough people see the growing industry as somewhere to build their careers (Druce, 2007). It can be an issue worth studying also in the hospitality industry of Nepal, a country with the 7.8 per cent of the GDP contribution (NTB, 2018) and at least 5 per cent of the total foreign currency earnings from the hospitality and tourism sector (MoCTCA, 2019).
With the exit of an employee, new employees have to be recruited, selected, oriented and trained. In fact, it costs an organization approximately one and half times the salary of the vacated position to replace an employee (Lips-Wiersma \& Hall, 2007). The negative effects not retaining its employees over a period of time ranges from loss of productivity, strained communication between management and employees, increased costs of hiring and training new employees, employers losing their invested resources to their competitors, loss of corporate memory, strained employee-customer relationships, and above all the morale of existing staff goes down (Kysilka \& Csaba, 2013).

Employee turnover can have a demoralizing effect on an organization, and it may severely affect the overall efficiency of the organization. This becomes even more critical in such service-oriented sectors as hospitality and hotel industry. There is generally a worldwide view that the hotel and catering industry has a number of personnel related problems and poor employment practices and conditions. Hence, it is increasingly important for practitioners and scholars to understand the reasons behind the high employee turnover rate in hotels (Qui, Hung, Haobin, \& York, 2015) and effective practices for high retention in the industry. For instance, within the private sector in the US, workers in leisure and hospitality had the lowest median tenure ( 2.2 years) and within hospitality sector, accommodation and food service (hotel) had the lowest median years of tenure, which was 2.1 years (USA Bureau of Labor Statistics, 2018). In Nepal, hotels constitute the 
most organized hospitality sector where a few public limited companies and international chain hotels are also involved, and they employ international employees as well. Consequently, employee retention is a matter of concern in hospitality industry in Nepal as well. As Farrell (2001) has argued, the value of employee retention in the hotel industry is irrefutable globally, and Nepal cannot be an exception to it. In view of this context and reality, the present study aims at exploring the HR retention practices and the effect moderating variables of management hierarchy, gender and age on their retention at five-star hotels in Nepal.

\section{Significance of the Study}

The study has sought to incorporate insights into how different retention strategies or practices can contribute towards making an organisation more attractive for different groups of employees; especially in five-star hotels of Nepal. The present study findings should prove beneficial for the HR managers of the hotels in figuring out different retention strategies to retain their quality employees. In addition, the findings will also enable the hotels to identify which retention strategies (namely, compensation, career growth, balanced work life and employer branding) matter most for different employees in terms of management hierarchy, age group and gender in retaining them in Nepalese five-star hotels and reduce labour turnover. The study findings can be instrumental in providing an actionoriented outline for Nepalese five-star hotels in matching their retention strategy with the needs of different groups of workforce and ensuring the acquisition of talented workers as well as successful retention of the existing employees that will all help improve their organisational attractiveness. The study should also be beneficial to add value to the existing body of knowledge in this area for the concerned scholars by forming the foundation upon which other related and replicated studies can be based under the similar or different settings.

\section{Objectives of the Study}

The major objective of the study is to explore the practices of employee retention and the effect of management hierarchy, gender and age on their retention at five-star hotels of Nepal. To achieve the main objective, the following specific objectives have been pursued:

- To assess the relationship of the HR retention practices with management hierarchy (level), and age group of the employees.

- To explore the differences of the human resource retention practices by management hierarchy (level), age group and gender of the employees.

- To assess the effect of management hierarchy (level), age group and gender on the HR retention practices.

\section{Theoretical Background}

The study has extracted the HR retention variables from three different models; namely, Met Expectations Model, Causal Model of Turnover and Integrated Process Model. The concept of 'Met Expectations' is described as 
the discrepancy between what a person encounters on this job in form of positive and negative experiences and what he expects to encounter (Porter \& Steers, 1973). Under this hypothesis, when an individual's expectationswhatever they are, are not met, his propensity to withdraw would increase. The model was developed by aligning it with Vroom's theory. The Causal Model of Turnover (Price, 2001) is a short reflection on the determinants of employees' voluntary turnover. The model has posited four individual exogenous variables that have direct impact on turnover intention; they are: general training, job involvement, positive affectivity and negative affectivity. General training has a significant positive relationship to turnover intention with assumption that increased general training produces a greater amount of turnover.

The third model adopted in the study is Jackofsky's (1984) 'Integrated Process Model', which is influenced by March and Simon (1958) and consists of desirability and ease of movements. In the basic model, ease of movement was referred to as the opportunities and alternatives provided by other organisations or extra-organisational factors, such as good labour market conditions. Whereas, the desirability of movement was implied to be the employee's job satisfaction, and for this, mostly referred to possible intraorganisational factors (Thwala, Ajagbe, Enegbuma, Bilau \& Long, 2012). These two movements were considered as main factors that would stimulate the intention of employees to leave the organisation voluntarily. Skilful employees would be rewarded with incentives such as higher bonus, year-end travelling vouchers and others compared to poor performers. Those rewards would definitely boost their contribution to their organisation; however, this factor is also expected to be negatively related or unrelated to job performance; as high performers might also receive better job alternatives from other organisations and quit the present employer to join competitors (Abdullah, Bilau, Enegbuma, Ajagbe, Ali, \& Bustani, 2012).

\section{Literature Review}

The literature review is directed at identifying and crystallising the four HR retention practices extracted from Met Expectations Model, Causal Model of Turnover and Integrated Process Model; namely, compensation, career growth, work-life balance and employer branding.

\section{Compensation}

Compensation is an important feature of human resources management (Torrington, Hall, \& Taylor, 2008). Compensation is defined as monetary benefits that accrue to employees both intrinsically and extrinsically. The compensation system that an organisation offers to its employees plays an important role in determining the commitment levels of employees and their retention (ILO, 2010). Gardner, Van, and Pierce (2004) highlighted that the compensation strategy is extremely important as the right compensation strategy helps to build the effective and competitive organisation and the wrong setting of the compensation strategy can destroy the organisation with low retention rates and not utilising the full potential of employees. An organisation can only 
be successful in its retention strategy if it offers competitive, market-related pay and benefits, because this motivates employees to become committed to the organisation (Lockwood, 2003). Compensation plans consists of explicit policies, practices and procedures, which are organised and managed as a whole (Armstrong, 2009).

Employees are likely to stay in organisations where they believe that their capabilities, contributions and efforts are appreciated (Davies, Taylor, \& Savery, 2001). Similarly, Tessema and Soeters (2006) concluded there is a positive correlation between compensation practices and employee retention. However, regardless of many studies reporting that financial rewards to be a poor motivating factor, remuneration packages still remain as a tactic employed by several organisations to improve employee commitment and retention (Mitchell, Holtom, Lee, Sablynski, \& Erez, 2001). However, the study showed that there was much individual variability in the importance of financial rewards for employee retention (Pfeffer, 1998).

In a Sri Lankan study, Kothalawala and Samarakoon (2018) examined the influence of job satisfaction of financial and internal executive officers in the public sector universities on their intention to leave. In addition to relationship with co-workers and working conditions, compensation (salary) — the research work foundwould make a significant positive effect on the job satisfaction that, in turn, would help retain the university employees in Sri Lanka. Therefore, an organisation's compensation strategy should be able to attract the right quality of employees, retain suitable employees, and to maintain equity amongst the employees. In view of the studies in different parts of the world, the present study has sought to investigate compensation as a retention strategy in Nepalese organisations.

\section{Career Growth}

In today's competitive environment, it is necessary that organisations create a work environment, which will enhance employee's career growth and development. Career development is a system, which is an organised, formalised and planned effort of achieving a balance between the individual career needs and the organisation's workforce requirements (Leiboiwitz, 1986). Career development practices are key strategic considerations for all organisations regardless of market or profile (Meyer \& Allen, 2001). It helps companies attract and retain high performing employees. Therefore, Schultze and Miller (2006) describe career development programmes as the processes through which employees' career goals and aspirations nurture to fulfilment; and at the same time aligning these career goals with the organisational needs, opportunities and goals.

The development of the capacity and capability of the organisation employees has a fundamental impact on efficiency, effectiveness, morale and profitability of an organisation (Armstrong, 2001). It has become evident that in order to foster the necessary growth and development of organisation, all organisations should develop a career development 
programme in the workplace (Prince, 2005) to ensure that employees develop before they move up the next higher level in the hierarchy, which benefits both individual employees and the organisation as a whole.

For organisations to acquire a high rate of employee retention, organisations should understand, encourage and enable their human capital with personal growth to ensure they acquire self-actualisation (Ontario, 2005), as an increment in employee retention bring a reduction in recruitment thus saving the organisation time and costs in recruitment and training (Philips \& Edward, 2008). Werther and Davis (2002) pointed that such a move will enhance organisational loyalty among employees, result in higher levels of job satisfaction, lower employee turnover, and fewer employee complaints. As a result, it is prudent for organisations to adopt the concept of career development to enhance employee retention. Hence, the present study aims at assessing whether career growth serves as a retention variable in Nepalese organisations or not.

\section{Work-life Balance}

Although there has been much research on work life balance (WLB), still it is an area of concern for any industry, and hospitality industry is also not an exception, either. Striking a good worklife balance is arguably a factor that helps retain employees in the organisation. Armstrong, Riemenschneider, Allen and Reid (2007) defined the quality of work-life as satisfying an employee's needs via the resources, activities and outcomes that arise from involvement in the workplace. The long and unsocial hours, low pay and often-low status of some tourism jobs, especially in the hospitality area neither easily attract new staff nor retain existing staff, as it hampers the work-life balance (Deery, 2008). Rowley and Purcell (2001) argued that the hospitality industry has higher than average skill shortages, labour turnover and hard-to-fill vacancies.

With specific attention to the impact on the work life balance, Smith and Gardner, (2007) suggested that conflict between work and family life is linked to job dissatisfaction and staff turnover. Deery and Shaw (1999) examined the role that a turnover culture had in employee satisfaction and organisational retention, and showed that if the organisation accepted high levels of employee turnover as normal, employees were less satisfied and retained. White, Hill, McGovern, Mills, \& Smearton (2003) argued that less satisfied and committed employees had a diminished quality of work-life and so they leave the organisation. Huang, Lawler, and Lei (2007) found that having a work-life balance decreased employees' intentions to leave an organisation. Glen (2012) found a strong positive relationship between work life balance, employee retention and career development aspects. McDonald, Brown, and Bradley (2005) identified flexible working conditions as one of the important dimensions in terms of the factors that influence employer attractiveness.

Guest (2002) studied the work-life balance by relating it to attitudes and values of two groups of workers; and reported that those in Generation $\mathrm{X}$ sought greater balance in their work 
and family life while older workers did not. The millennial employees are unlikely to remain with the same company or industry for their entire careers as old generations do (Solnet, Krali, \& Kandampully, 2012). In case of the work-life balance for women in the hospitality industry, Doherty (2004) found that it was the very long hours and the lack of flexibility - both worklife balance factors - that deterred women from seeking senior levels outside their current employer. It has therefore recognised work-life balance as a factor affecting employee retention in organisations.

\section{Employer Branding}

Employer branding is a relatively new approach towards recruiting and retaining the best possible human talent within a recruiting environment that is becoming increasingly competitive and it has captured considerable attention in recent times. Attracting skilled people is equally as important as acquiring the equipment or technological resources that are required to build competitive advantage (Backaus \& Tikoo, 2004). The employer-branding concept got the attention due to the growing competition among rival companies, which required talent to compete and achieve growth and sustainability (Mosley, 2007). Ambler and Barrow (1996) probed into the concept of employer branding by focusing on four dimensions; namely, the interest value, social value, development value and application value, and opined the way organisational brands communicate the benefits of using a product or service to potential consumers; employer brands communicate the benefits of employment to potential employees.
Furthermore, Dabirian, Kietzmann and Hoda (2017) elaborated two dimensions on employer branding; namely, management value and work life balance value.

The theoretical perspective of employer branding has largely been been guided by the Human Capital Theory and the Resource-Based View (RBV) of the firm. According to the theoretical viewpoint, employerbranding concept is the 'sum of a company's efforts to communicate to existing and prospective staff that the organisation is a desirable place to work (Ewing, Leyland, Nigel, \& Pierre, 2002). Employers, who have high employer brand value are perceived by potential employees as more attractive than those with lower employer brand value (Berthon \& Ewing, 2005). According to the Conference Board report on employer branding (Collins, 2006), organisations have found that effective employer branding leads to competitive advantage, helps employees internalise company values and assists in employee retention.

Davies (2008) showed the role of the employer brand in influencing employee's perceived differentiation, affinity, satisfaction and loyalty. Dell and Ainspan, (2001) found that effective employer branding led to competitive advantage that would help employees internalise company values and assists in retaining employees. Organisations with a strong brand image can acquire employees at comparatively low cost, improve employee relations, increase employee retention and offer lower pay scales as compared to its rivals (Riston, 2002). Managers can use employer branding 
as a shade under which they can channel different employee recruitment and retention activities into a coordinated human resource strategy. Accordingly, employers can control brand power to engage their employees in emotional ways to achieve change, outstanding results or increase attraction and retention. It is, therefore, relevant to examine the role of employer branding retaining employees in Nepal also.

\section{Methods}

The design employed for this study is cross-sectional and descriptive in nature, as it can collect the data on the phenomenon, which cannot be directly observed. A descriptive survey- a systematic, non-experimental method for gathering information from a sample for describing the attributes of the larger chosen population — best fits in ascertaining and describing characteristics of the studied variables and allows for the use of questionnaires.

The target population of the study is the five-star hotels in Nepal, which have been in operation for at least 10 years. The official data of the Hotel Association of Nepal (HAN) have put the total number of 5-star hotels in Nepal at eight (HAN, 2018) of which three are the international chains of hotels in Kathmandu and the rest are just domestic. The study has used a stratified random sampling method to select six five-star hotels stationed in the capital valley of Kathmandu; they represent 75 per cent of the defined population. Out of the six hotels sampled, three belong to the international chain of hotels and three do not. The list of sample hotels is in Appendix A.

Furthermore, the population of the respondents consists of the employees working at the front office, housekeeping, and service and food production, of the sampled hotels. Prior to determination of the sample size, the information about the number of frontline employees (i.e., those from front-office, housekeeping, and service and food production departments) of the hotels in each of the sampled hotels was obtained from the human resource departments of the respective hotels. The study used a convenience sampling method to determine the required sample size of 278 respondents from the population of 976 front-line employees of the sample hotels, which followed the rule that requires sampling it at 95 per cent confidence level with \pm 5 percent margin of error (Encyclopedia of Survey Research Methods, 2008). The study has covered employees from the three management hierarchies: The top-level managers are the departmental heads; mid-level managers the assistant departmental heads and sectional heads within the department, while low-level employees are non-supervisory employees (other than top managers, assistant managers and mid-level managers) of the sampled hotels. Appendix B exhibits details of the sample respondents.

The study used a structured questionnaire to collect required data using a non-disguised approach and validated with content validity by scrutinising it through HRM experts. Finally, after required modifications, the questionnaire was administered on 343 potential respondents within a 
period of 37 days from 20th July 2018 to 26th August 2018. The study used a self-administered process in two hotels and with the help of assistants in rest four sample hotels by following dropand-pick method, as this technique is an effective means to reduce potential non-response bias through increased response rate. There was a follow-up to collect the questionnaires on time and offered assistance to the respondents having difficulty in completing the questionnaires. Finally, altogether 301 filled-up questionnaires out of the 343 distributed ones were collected, and 292 questionnaires were found to be complete and usable; it has posted a valid response rate of 85.13 per cent, a success rate high enough to do without a non-response bias test.

\section{Analysis Tools}

The study has also used the nonparametric tests after fulfilling all the assumptions to test the formulated hypotheses. The study has used Spearman rank correlation, Jonckheere-Terpstra test, MannWhitney $U$ test, and measure of association (effect size) of the moderating variables on the variables to infer about for the population of the study using a significant value approach at 95 per cent confidence level. The effect size for JonckheereTerpstra test and for post hoc and Mann-Whitney U test analysis has been calculated using the formulae as suggested by Cohen (2008) and Fritz, Morris and Richler (2012).

$$
r(\text { Jonckhree }- \text { Terpstra test })=\frac{\text { Standardized } J-T \text { test statistic }}{\sqrt{N}}
$$

$r($ Post hoc and Mann Whitney U test $)=\frac{\text { Standardized test statistic (z) }}{\sqrt{N}}$

Where;

$R=$ measure of association or effect size

$N=$ number of cases

All the calculated R-values are then compared with Cohen's d value which has $r$ equivalent to $d^{*}$ as exhibited in Table 1. Rosenthal and Rosnow (1984) noted that the thresholds for small, medium and large effects are not consistent for $\mathrm{r}$ and $\mathrm{d}$; it is evident in Table 1. Although a small $\mathrm{d}=.20$ is equivalent to a small $\mathrm{r}=.10$, the $\mathrm{r}$ equivalent of a medium-sized $\mathrm{d}=$ 0.5 can be rated as a small effect (.24, not .30) in the correlational metric. Thus, Cohen requires larger effects when measuring the strength of association. 
Table 01: Comparison of measure of association $d$ vs $r$

\begin{tabular}{|l|c|c|c|}
\hline Effect & d & r & r equivalent to d* \\
\hline Small & 0.2 & 0.1 & 0.10 \\
\hline Medium & 0.5 & 0.3 & 0.24 \\
\hline Large & 0.8 & 0.5 & 0.37 \\
\hline
\end{tabular}

Note: Based on Rosenthal \& Rosnow (1984)

\section{Results and Discussion}

Appendix $A$ exhibits the sample characteristics under three strata of respondents. The first stratum is the level of respondents enshrined in top, middle and entry-level jobs of the respondents constituting 15.8, 25.3 and 58.9 per cent, respectively. Similarly, the second stratum is the age groups: those aged 40 years (12.7 per cent), 3040 (38.0 per cent) and below 30 years (49.3 per cent). Finally, on the genderbased stratum, there were 63.7 male and 36.3 per cent female respondents.

The Table 2 exhibits the Spearman rank correlation measured on practices of employee retention strategies with management hierarchies (levels) and age groups of employees. The result suggests that the management hierarchy (level) of the respondents has negative and significant relationship with compensation $(-0.210)$, and positive and significant relationship with employer branding (0.263). It implies that hotel employees at the lower hierarchies recognise compensation, as an important determinant for their retention and toplevel employees prefer termed it less important, whereas the top-level employees perceive employer branding as the most important factor for their retention and it is of less importance for lower level employees in Nepalese hotels.

Table 2: Spearman Rank Correlations

\begin{tabular}{|c|c|c|c|c|c|c|}
\hline Variables & Com. & $\begin{array}{l}\text { Career } \\
\text { growth }\end{array}$ & WLB & $\begin{array}{c}\text { Emp. } \\
\text { Brand. }\end{array}$ & $\begin{array}{c}\text { Mgt. } \\
\text { Hierarchy } \\
\text { (Level) }\end{array}$ & Age \\
\hline Compensation & 1 & & & & & \\
\hline Career growth & $\begin{array}{l}-.287 * * \\
(0.001)\end{array}$ & 1 & & & & \\
\hline $\begin{array}{l}\text { Balanced work } \\
\text { life }\end{array}$ & $\begin{array}{l}-.332 * * \\
(0.001)\end{array}$ & $\begin{array}{l}-.480 * * \\
(0.001)\end{array}$ & 1 & & & \\
\hline $\begin{array}{l}\text { Employer } \\
\text { branding }\end{array}$ & $\begin{array}{l}-.430 * * \\
(0.001)\end{array}$ & $\begin{array}{l}-.247 * * \\
(0.001)\end{array}$ & $\begin{array}{l}-.179 * * \\
(0.002)\end{array}$ & 1 & & \\
\hline
\end{tabular}




\begin{tabular}{lllllll}
\hline \multicolumn{1}{c}{ Variables } & Com. & $\begin{array}{c}\text { Career } \\
\text { growth }\end{array}$ & WLB & $\begin{array}{c}\text { Emp. } \\
\text { Brand. }\end{array}$ & $\begin{array}{c}\text { Mgt. } \\
\text { Hierarchy } \\
\text { (Level) }\end{array}$ & Age \\
\hline $\begin{array}{l}\text { Management } \\
\text { Hierarchy }\end{array}$ & $-.210^{* *}$ & -0.054 & 0.066 & $.263^{* *}$ & & \\
(Level) & $(0.001)$ & $(0.358)$ & $(0.259)$ & $(0.001)$ & 1 & \\
Age Group & 0.031 & $-.285^{* *}$ & $.156^{* *}$ & $.143^{*}$ & $.511^{* *}$ & 1 \\
& $(0.592)$ & $(0.001)$ & $(0.008)$ & $(0.015)$ & $(0.001)$ & \\
\hline
\end{tabular}

** Correlation is significant at the 0.01 level (2-tailed). $*$ Correlation is significant at the 0.05 level (2-tailed).

Source: Calculations based on Authors' Survey, 2018

Similarly, the relationship of age group with career growth, work-life balance and employer branding are also statistically significant with the coefficients of $-0.285,0.156$ and 0.143 , respectively. It reveals an inverse relationship existing between age groups and career-growth opportunities; that is, lower level employees are more career-conscious, and it acts as an important retention strategy for them. The result also shows a direct relationship existing between age group and balanced work-life as well as employer branding.

The study has performed a JonckheereTerpstra test on retention practices across the three management hierarchies and age groups of the respondents to identify if the population across these groups differ. Table 3 shows that there is a statistically significant difference in employees' preference for compensation and employer branding between the different levels with observed J-T statistic of 9542 and 15212, $\mathrm{p}=0.001$ and 0.001 with a measure of association of 0.206 and 0.265 , respectively. Similarly, Table 3 shows a statistically significant difference in ranking of career growth, balanced work life and employer branding between the different age groups, with observed J-T statistic of 9222.5, 14548.5 and $14510.5 \quad(p=$ $0.001,0.010$ and 0.013 with an effect size of $-0.279,0.152$ and 0.145 , respectively).

\section{Table 3: Jonckheere-Terpstra test}

\begin{tabular}{|l|l|l|l|l|}
\hline $\begin{array}{l}\text { Panel A: Median difference test on mean rank basis across management hierarchies } \\
\text { (levels) }\end{array}$ \\
\hline \multicolumn{1}{|c|}{ Statistic/Variables } & Com. & $\begin{array}{c}\text { Career } \\
\text { growth }\end{array}$ & $\begin{array}{c}\text { Balanced } \\
\text { work life }\end{array}$ & $\begin{array}{c}\text { Employer } \\
\text { branding }\end{array}$ \\
\hline Observed J-T Statistic & 9542 & 11408 & 12812 & 15212 \\
\hline Mean J-T Statistic & 12022 & 12022 & 12022 & 12022 \\
\hline $\begin{array}{l}\text { Std. Deviation of J-T } \\
\text { Statistic }\end{array}$ & 702.860 & 709.096 & 689.308 & 703.499 \\
\hline
\end{tabular}




\begin{tabular}{|l|l|l|l|l|}
\hline Std. J-T Statistic & -3.528 & -0.866 & 1.146 & 4.534 \\
\hline Asymp. Sig. (2-tailed) & 0.001 & 0.387 & 0.252 & 0.001 \\
\hline Measure of association & -0.206 & -0.051 & 0.067 & 0.265 \\
\hline Panel B: Median difference test on mean rank basis across age group \\
\hline \multicolumn{1}{|c|}{ Statistic/Variables } & Com. & \multicolumn{1}{|c|}{$\begin{array}{c}\text { Career } \\
\text { growth }\end{array}$} & $\begin{array}{c}\text { Balanced } \\
\text { work life }\end{array}$ & \multicolumn{1}{|c|}{$\begin{array}{c}\text { Employer } \\
\text { branding }\end{array}$} \\
\hline Observed J-T Statistic & 13138.5 & 9222.5 & 14548.5 & 14510.5 \\
\hline Mean J-T Statistic & 12709.5 & 12709.5 & 12709.5 & 12709.5 \\
\hline $\begin{array}{l}\text { Std. Deviation of J-T } \\
\text { Statistic }\end{array}$ & 724.138 & 730.563 & 710.176 & 724.796 \\
\hline Std. J-T Statistic & 0.592 & -4.773 & 2.589 & 2.485 \\
\hline Asymp. Sig. (2-tailed) & 0.554 & 0.001 & 0.010 & 0.013 \\
\hline Measure of association & 0.035 & -0.279 & 0.152 & 0.145 \\
\hline Source: Based on Authors' Survey, 2018 & & \\
\hline
\end{tabular}

Further, there is no median difference across various age groups $(0.554)$ for compensation as the most preferred HR retention strategy. These findings comply with the results of Spearman rank correlation coefficients and significance.
The table 4 and table 5 present the results of the post hoc analysis (pairwise comparison) performed on the variables; they have been found to be

Table 4: Post hoc analysis across management hierarchies (levels)

Panel A: Pair-wise comparison of median differences across management hierarchies (levels) for compensation

\begin{tabular}{lccccccc}
\hline Sample1-sample 2 & $\begin{array}{c}\text { Test } \\
\text { Stat. }\end{array}$ & $\begin{array}{c}\text { Std. } \\
\text { error }\end{array}$ & $\begin{array}{c}\text { Std. } \\
\text { test }\end{array}$ & Sig. & Adj. sig & N & Asso. \\
\hline $\begin{array}{l}\text { Entry level - Top } \\
\text { level }\end{array}$ & 3354 & 358.23 & -1.680 & 0.046 & 0.139 & 218 & -0.114 \\
$\begin{array}{l}\text { Entry level - } \\
\text { Middle level }\end{array}$ & 4068 & 489.438 & -4.691 & 0.001 & 0.001 & 246 & -0.299 \\
$\begin{array}{l}\text { Top level - Middle } \\
\text { level }\end{array}$ & 2120 & 178.777 & 2.338 & 0.990 & 1.000 & 120 & 0.213 \\
\hline
\end{tabular}


Panel B: Pair-wise comparison of median differences across management hierarchies (levels) for employer branding

\begin{tabular}{|c|c|c|c|c|c|c|c|}
\hline Sample1-sample 2 & $\begin{array}{c}\text { Test } \\
\text { statistic }\end{array}$ & $\begin{array}{l}\text { Std. } \\
\text { error }\end{array}$ & $\begin{array}{l}\text { Std. test } \\
\text { statistic }\end{array}$ & Sig. & $\begin{array}{l}\text { Adj. } \\
\text { sig }\end{array}$ & $N$ & Asso. \\
\hline $\begin{array}{l}\text { Middle level - Top } \\
\text { level }\end{array}$ & 1656 & 175.887 & -0.262 & 0.603 & 1.000 & 120 & -0.024 \\
\hline $\begin{array}{l}\text { Middle level - } \\
\text { Entry level }\end{array}$ & 8496 & 489.475 & 4.356 & 0.001 & 0.001 & 246 & 0.278 \\
\hline $\begin{array}{l}\text { Top level - Entry } \\
\text { level }\end{array}$ & 5060 & 364.045 & 3.033 & 0.001 & 0.004 & 218 & 0.205 \\
\hline
\end{tabular}

Source: Calculations based on Authors' Survey, 2018

significantly different for the three management hierarchies (levels) and age groups of the respondents as shown by the Jonckheere-Terpstra test exhibits the sample average rank. The average mean rank for compensation for top level, middle level and entrylevel employees are $150.50,183.18$ and 129.65 respectively; it evinces that entry-level employees recognised a better compensation as a stronger retention strategy in Nepalese hotels.

Panel A in table 4 shows the presence of significant median differences across entry and middle level (0.001) and entry and top level $(0.046)$ with medium effect size $(0.299)$ and with small effect size (0.114), respectively. If the data results were any indication of the fact, hotel managers should treat the different levels of employees differently to retain them.

Similarly, the Panel B in Table 4 evinces the presence of significant difference in the mean rank of employer branding across middle and entry levels (0.001), and top and entry levels (0.004) with moderate effect size of 0.278 and small effect size of 0.205 , respectively. The middle level and top- level employees valued employer branding as the most important retention strategies with mean rank values of 117.07 and 123.50, respectively; whereas it was 165.31 for the entry-level employees.

The Panel A in table 5 exhibits the career growth as the most preferred factor for the retention of the employees aged below 30 and 30-40 years, with a mean rank value of 126.89 and 152.58 , respectively. It is 204.58 for the age group of above 40. And, Panel A depicts that there exists the difference in career growth as a motivating factor as a retention strategy between the age groups: below 30 and $30-40$, below 30 , above 40 and 30-40, and above 40 years. The large effect size of age groups on career growth as a motivating factor was found for the age groups between below 30 and above 40 years $(0.406)$, just moderate for the group of 30-40 and above 40 years $(0.252)$ and small effect size for the group of below 30 and $30-40$ years (0.149).

Similarly, Panel B depicts the existence of difference between the age group of $30-40$ and that below 30 years in case 
of balanced work life as a motivating factor for the employees not to quit the organisation, with small effect size of 20.22. The balanced work life is the most motivating retention strategy for the age group of 30-40 years and then for the age group of above 40 years with the mean rank of 125.76 and 148.82 respectively (See Appendix C). Finally, elderly hotel employees value employer branding as the most important retaining factor, as the average ranks of employer branding were $108.18,148.46$ and 154.83 for age groups of above 40, 30-40 and below 30 years (See Appendix C). Panel C shows the difference in employer branding as effective retention strategy existing between the age group of above 40 and $30-40$, above 40 , and below 30 years, with the small effect size of 0.229 and 0.222 , respectively.

\section{Table 5: Post-Hoc Analysis across Age Groups}

\begin{tabular}{|c|c|c|c|c|c|c|c|}
\hline \multicolumn{8}{|c|}{ Panel A: Pair-wise comparison of median differences across age group for career growth } \\
\hline Sample1-sample 2 & Test statistic & $\begin{array}{l}\text { Std. } \\
\text { error }\end{array}$ & $\begin{array}{l}\text { Std. test } \\
\text { statistic }\end{array}$ & Sig. & $\begin{array}{c}\text { Adj. } \\
\text { sig }\end{array}$ & $\mathrm{N}$ & Asso. \\
\hline Below $30-30-40$ & 6654 & 562.75 & -2.378 & 0.009 & 0.026 & 255 & -0.149 \\
\hline Below 30 - Above 40 & 1178 & 272.05 & -5.462 & 0.001 & 0.001 & 181 & -0.406 \\
\hline 30-40 - Above 40 & 1390 & 216.62 & -3.061 & 0.001 & 0.003 & 148 & -0.252 \\
\hline \multicolumn{8}{|c|}{ Panel B: Pair-wise comparison of median differences across age group for balanced work life } \\
\hline Sample1-sample 2 & Test statistic & $\begin{array}{l}\text { Std. } \\
\text { error }\end{array}$ & $\begin{array}{l}\text { Std. test } \\
\text { statistic }\end{array}$ & Sig. & $\begin{array}{l}\text { Adj. } \\
\text { sig }\end{array}$ & $\mathrm{N}$ & Asso. \\
\hline $30-40$ - Above 40 & 1676.5 & 216.74 & -1.739 & 0.959 & 1.000 & 148 & -0.143 \\
\hline 30-40 - Below 30 & 9917 & 546.95 & 3.520 & 0.001 & 0.001 & 255 & 0.220 \\
\hline Above 40 - Below 30 & 2955 & 259.84 & 1.120 & 0.131 & 0.394 & 181 & 0.083 \\
\hline \multicolumn{8}{|c|}{ Panel C: Pair-wise comparison of median differences across age group for employer branding } \\
\hline Sample1-sample 2 & Test statistic & $\begin{array}{l}\text { Std. } \\
\text { error }\end{array}$ & $\begin{array}{l}\text { Std. test } \\
\text { statistic }\end{array}$ & Sig. & $\begin{array}{c}\text { Adj. } \\
\text { sig }\end{array}$ & $\mathrm{N}$ & Asso. \\
\hline Above 40 - 30-40 & 2654.5 & 215.34 & 2.791 & 0.003 & 0.008 & 148 & 0.229 \\
\hline Above 40 - Below 30 & 3481 & 273.29 & 2.989 & 0.001 & 0.004 & 181 & 0.222 \\
\hline 30-40 - Below 30 & 8375 & 557.43 & 0.687 & 0.246 & 0.738 & 255 & 0.043 \\
\hline
\end{tabular}

Source: Calculations based on Authors' Survey, 2018 
Table 6: Mann-Whitney U test

\begin{tabular}{lcccc}
\hline \multicolumn{1}{c}{ Variables } & Com. & $\begin{array}{c}\text { Career } \\
\text { growth }\end{array}$ & $\begin{array}{c}\text { Balanced work } \\
\text { life }\end{array}$ & $\begin{array}{c}\text { Employer } \\
\text { branding }\end{array}$ \\
\hline Mean rank male & 136.74 & 124.81 & 164.62 & 160.49 \\
Mean rank female & 163.63 & 184.56 & 114.71 & 121.95 \\
Mann-Whitney U & 8042 & 5824 & 6488 & 7256 \\
Wilcoxon W & 25433 & 23215 & 12159 & 12927 \\
Z & -2.732 & -6.015 & -5.169 & -3.911 \\
Asymp. Sig. (2-tailed) & 0.006 & 0.001 & 0.001 & 0.001 \\
Measure of & -0.160 & -0.352 & -0.302 & -0.229 \\
association & &
\end{tabular}

Source: Calculations based on researchers' survey, 2018

Table 6 reports significant median differences across the gender of the respondents in compensation, career growth, balanced work life and employer branding as the effective HR retention strategies. Male employees perceive compensation and career growth as the strong motivator for HR retention, as mean rank values of male respondents are 136.74 and 124.81 for compensation and career growth respectively, while those for their female counterparts are 163.63 and 184.56 , respectively.

Likewise, female respondents perceived balanced work life and employer branding as those that make them stay on with the current employee, as mean rank values are 114.71 and 121.95, against those of 164.62 and 160.49 for male employees, respectively. The effects of gender on perceiving career growth $(0.352)$ and balanced work life (0.302) are medium as the important motivator for retention. Similarly, the measure of association values of 0.160 and 0.229 indicate that the effect size of gender on compensation and employer branding is just small, as a retention strategy in Nepalese five-star hotels in Nepal.

\section{Conclusion}

The results of the data analysis evinces that there is a negative, significant relationship of management hierarchy level with compensation $(-0.210 * *)$ and a positive, significant relationship with employer branding $(0.263 * *)$. These are the evidence that rewards and compensation help retain entry-level employees, while employer branding is a strong retention measure for those on higher hierarchies. It reveals the finding that top-level employees of the Nepalese five star hotels recognise the employer branding as the HR retention strategy applicable to them while they identify compensation (direct pay scale) as the least influential HR retention tactic. On contrary, for the entry-level employees in Nepalese five star hotels, compensation is the strongest HR retention motivator, and employer branding the weakest one. The statistically significant relationship existing between compensation and employer branding $(-0.430 * *)$ implies 
that in case of management hierarchy, the Nepalese hotel employees' preference swings between compensation and employer branding as a factor that motivates them to stay with the current employer. The finding has matched with that of Moncraz, Zhao and Kay (2009) that was specific about the workforce categories (hierarchies) and noted that employer branding and compensation (reward) would reduce HR turnover and increase commitment among managers and entry-level employees respectively.

Similarly, the relationship between age group and career growth $\left(-0.285^{* *}\right)$, balanced work life $\left(0.156^{* *}\right)$, and employer branding $\left(0.143^{* *}\right)$ indicates that younger employees view career growth opportunities as the strongest HR retention factor that could retain them with their current employment. The practices of balanced work life and employer branding do not motivate such younger employees to continue with the current employer (as retention strategies). This conclusion is supported by the relationships between each pair of career growth and balanced work life $\left(-0.480^{* *}\right)$, career growth and employer branding $\left(-0.247^{* *}\right)$, balanced work life and employer branding $(-0.179 * *)$. The results match with the findings of Prince (2005) and Deery (2008), who have posited that young employees first focussed on the career (professional career) and subsequently devoted more time to other areas of their lives (or downshifting). In addition, other employees emphasised on the significance of a healthy balance between personal and professional life (i.e., balance work life) to improve the HR retention efforts. Further, it can also inferred from the data results that significant differences exist across male and female hotel employees concerning preferences of various retention practices at their workplaces as career growth is the strongest and balanced work life, the weakest measure to retain male hotel employees in Nepal.

\section{Implications}

Employee turnover is always costly, as it requires the employer to replace the incumbents with fresh ones. Therefore, the employer pursuing appropriate HR practices can enable employees to understand their career path and plan for the future resulting into a win-win satiation for both employee and employer. In this regard, the outcomes of the present study have met the objectives of the study in two specific aspects. Firstly, the outcomes add new insights into the body of knowledge; specifically the one regarding the moderating effect of management hierarchy, age group and gender on the important determinants of HR retention in Nepalese five-star hotels. Secondly, HR managers and other line managers and employers of Nepalese five-star hotels could use the study outcomes to facilitate decisions on how best to practise the retention strategies to retain different human resources and talents in terms of their management hierarchy, age group and gender, and get the most out of their valued employees. For future studies, the study recommends a triangulation method that would provide both quantitative and qualitative techniques. Qualitative technique would bring forth the underlying and in-depth explanation of the studied variables and moderating 
effects on them. Other factors such as cultural effect can also be investigated.

\section{Limitations}

The present study has considered only an employee perspective, and ignored the employer perspective, which might limit the interpretations from being widely acceptable. The present study has covered only four dimensions of retention strategies or practices, viz., compensation, career growth, balanced work-life and employer branding. The study has covered only the five-star hotels, and ignored other types of hotels (below 5-star and non-star hotels) as well as other hospitality-related businesses. As regards the respondents, the study has covered the employees only from the front-office, housekeeping, and service and food production departments of the hotels and not encompassed other departments.

The truthfulness of the opinions provided by the respondents may have affected the study findings. The study is based on current scenario and the opinions of the respondents may differ with time and with other industry sectors. These limitations could confine the generalizability of the findings

\section{References}

Abdullah, A., Bilau, A. A., Enegbuma, W. I., Ajagbe, A. M., Ali, K. N., \& Bustani, S. A. (2012). Small and medium sized construction firms job satisfaction and evaluation in Nigeria. International Journal of Social Science and Humanity, 2(1), 35-40.

Ambler, T., \& Barrow, S. (1996). The employer brand. Journal of Brand Management, 4(3), 185-206.

Arachchige, B., \& Alan, R. (2013). Employer attractiveness: Comparitive perceptions of undergraduate and postgraduate students. Sri Lankan Journal of Human Resource Management, 4, 33.

Armstrong, D., Riemenschneider, C., Allen, M., \& Reid , M. (2007). Advancement, voluntary turnover and women in IT: A cognitive study of work-family conflict. Information and management, 44, 142-153.

Armstrong, M. (2001). Human Resource Management Practice: Handbook (8th ed.). London: Kegan Page.

Armstrong, M. (2009). Armstrong's Handbook of Human Resource Management Practice (11th ed.). London: Kogan Page.

Backaus, K., \& Tikoo, S. (2004). Conceptualizing and researching employer branding. Career Development International, 9(5), 501-517.

Bereau of Labor Statistics. (2018). BLS:US Department of Labor. Retrieved August 15, 2019, from https://www.bls.gov/news.release/pdf/tenure.pdf 
Berthon, P., \& Ewing, M. (2005). Captivating company: Dimensions of attractiveness in employer branding. International Journal of Advertising, 24(2), 151-172.

Brown, E. A., Thomas, N. J., \& Bosselman, R. H. (2015). Are they leaving or staying: A qualitative analysis of turnover issues for Generation $\mathrm{Y}$ hospitality employees with a hospitality education. International Journal of Hospitality Management, 46, 130-137.

Caplan, G., \& Teese, M. (1997). Survivors: How to Keep Your Best People on Board after Downsizing (1st ed.). CA: Davies-Black Publishing.

Cohen, B. (2008). Explaining Psychological Statistics (3rd ed.). New York: John Wiley \& Sons.

Collins, C. Y. (2006). The interactive effects of recruitment practices and product awareness on job seekers: Employer knowledge and application behaviors. Journal of Applied Psychology, 92(1), 180-190.

Dabirian, A., Kietzmann, J., \& Hoda, D. (2017). A great palce to work:Understanding crowdsources employer branding. Journal of Brand Management, 60, 197205.

Davies, D., Taylor, R., \& Savery, C. (2001). The role of appraisal, remuneration and training in improving staff relations in the Western Australian accommodation industry: A comparative study. Journal of European Training, 25(6/7), 366-373.

Davies, G. (2008). Employer branding and its influence on managers. European Journal of Marketing, 42(5/6), 667-681.

Deery, M. (2008). Talent management work life balance and retention strategies. International Journal of Contemporary Hospitality Management, 20(7), 792806.

Deery, M., \& Shaw, R. (1999). An investigation of the relationship between employee turnover and organizational culture. Journal of Hospitality and Tourism Research, 23(4), 387-400.

Dell, D., \& Ainspan, N. (2001). Engaging employees through your branad. Conference Board. Washington D.C.

Doherty, L. (2004). Work-life balance initiatives: Implications for women. Employee Relations, 26(4), 433-452.

Druce, C. (2007). Skills strategy a positive step, say employers. Caterer \& Hotelkeeper, 197(4467), 5-12. 
Encyclopedia of Survey Research Methods. (2008). Sage Publication. (P. J. Lavrakas, Editor) Retrieved May 8, 2018, from http://methods.sagepub.com: http://http://methods.sagepub.com/reference/encyclopedia-of-surveyresearch-methods/n507.xml

Ewing, M. T., Leyland, F. P., Nigel , M., \& Pierre, B. (2002). Employment branding in the knowledge economy. International Journal of Advertising, 21, 3-22.

Farrell, K. (2001). Human resource issues as barriers to staff retention and development in the tourism industry. Irish Journal of Management, 22(2), 121-142.

Fladetta, G., Fasone , V., \& Provenzano, C. (2013). Turnover in the hospitality industry: Can reciprocity solve the problem? Revista de Turismoy Patrimonio Cultural, 11(4), 583-595. Retrieved January 12, 2018, from file://C:/Users/User/Downloads/PS0413_06.pdf

Fritz, C. O., Morris , P. E., \& Richler, J. J. (2012). Effect size estimates: Current use, calculations and interpretation. Journal of Experimental Psychology: General, 141(1), 2-18.

Gardner, D. G., Van, D. L., \& Pierce, J. L. (2004). The effects of pay level on organization based self esteem and performance: A field study. Journal of Occupational Psychology, 77(3), 307-322.

Glen, C. (2012). Key skills retention and motivation: The war for talent still rages and retention is the high ground. Industrial and Commercial Training, 38(1), 3745.

Guest, D. (2002). Perspectives on the study of work-life balance. Social Science Information, 41, 255-279.

HAN. (2018, September). 5-Star Hotels. Retrieved July 29, 2018, from Hotel Association of Nepal: http://www.hotelassociationnepal.org.np/

Hanzaee, K., \& Mirvaisi, N. (2011). Implementing gronroos service quality model: The role of image and service quality perception on customer satisfaction in the Iran hotel industry. Journal of Basic and Applied Scientific Research, 1020.

Huang, T., Lawler, J., \& Lei, C. (2007). The effects of quality of work life on commitment and turnover intention. Social Behavior and personality, 35(6), 735-750.

ILO. (2010). International Labor Migration. A Rights Based Approach. Geneva: ILO. 
Jackofsky, E. F. (1984). Turnover and job performance: An integrated process model. The Academy of Management Review, 9(1), 74-83.

Kothalawala, C. G., \& Samarakoon, S. M. (2018). Job satisfaction and intention to leave: A study of financial and internal audit executive staff of public universities in Sri Lanka. Kelaniya Journal of Human Resource Management, 13(1), 49-60. doi:http://doi.org/10.4038/kjhrm.v13i1.49

Kysilka, D., \& Csaba, N. (2013). Employee turnover in the hospitality industry. Seria Stiinte Economice Timisoara, 19, 377-384. Retrieved December 6, 2017, from http://fse.tibiscus.ro/activitate/anale-seria-stiinte-economice-timisoara

Leiboiwitz, B. (1986). Designing Career Development Systems. Sanfrancisco: JosseyBass Publishers.

Lips-Wiersma, M., \& Hall, D. T. (2007). Organizational career development is not dead: A case study on managing the new career during organizational change. Journal of Organizational Behavior, 28, 771-792.

Lockwood, N. R. (2003). Work life balance: Challenges and solutions. Research Quarterly, 2, 1-10.

March, J. G., \& Simon, H. A. (1958). Organizations. New York: Wiley.

McDonald, P., Brown, K., \& Bradley, L. (2005). Explanations for the provision utilization gap in work life policy. Women in Management Review, 20(1), 3755.

Meyer, J., \& Allen, N. (2001). Commitment in the Workplace. California: SAGE Publications.

Mitchell, T. R., Holtom, B. C., Lee, T. W., Sablynski, C. J., \& Erez, M. (2001). Why people stay: Using job embeddedness to predict voluntary turnover. The Academy of Management Journal, 44(6), 1102-1121.

MoCTCA (2019 May). Nepal Tourism Statistics, Ministry of Culture, Tourism and Civil Aviation. The Government of Nepal. Retrieved from http://tourism.gov.np/files/statistics/19.pdf

Moncarz, E., Zhao, J., \& Kay, C. (2009). An exploratory study of US lodging properties' organizational practices on employee turnover and retention. International Journal of Contemporary Hospitality Management, 21(4), 437458.

Mosley, R. W. (2007). Customer experience, organizational culture and the employer brand. Journal of Brand Management, 15, 23-134. 
Ogbonna, E., \& Lloyd, C. H. (2002). Managing organizational culture: Insights from the hospitality industry. Human Resource Management Journal, 12(1), 33-53.

NTB (2018). Nepal Tourism Board (Mar 28, 2018), The Government of Nepal (Official website). https://trade.welcomenepal.com/

Ontario, R. N. (2005). Human resource management and firm performance. Journal of Management, 21(71), 1-38.

Oster, S. M. (2004). Strategic Management for Non-Profit Organizations: Theory of Cases. London: Macmillan Publishers Ltd.

Pfeffer, J. (1998). Seven practices of successful organizations. California Management Review, 40(2), 96-124.

Philips, J. J., \& Edward, L. (2008). Managing talent retention: An ROI approach (1st ed.). Kindle edition: Pfeiffer.

Porter, L. W., \& Steers, R. M. (1973). Oganizational, work, and personal factors in turnover in employee turnover and absenteeism. Psychological Bulletin, 80(2), 151-176.

Price , J. (2001). Reflections on the determinants of voluntary turnover. International Journal of Manpower, 22, 600-624.

Prince, B. J. (2005). Career-focused employee transfer process. Career Development International, 10(4), 293-309.

Qui, H., Hung, K., Haobin, Y. B., \& York, Q. (2015). Exploring antecedents of employee turnover intention - Evidence of China's hotel industry. Journal of China Tourism Research, 11(1), 53-66.

Riston, J. (2002). Impact of employer branding on employee attraction and retention. European Journal of Business and Management, 4, 22-39.

Rosenthal, R., \& Rosnow, R. L. (1984). Applying Hamlet's question to the ethical conduct of research: A conceptual addendum. American Psychologist, 39(5), 561-563.

Rowley, G., \& Purcell, K. (2001). As cooks go, she went: Is labor churn inevitable? International Journal of Hospitality Management, 20, 163-185.

Schultze, G., \& Miller, C. (2006). The search for meaning and career development. Career Development International, 9(2), 42-52.

Smith, J., \& Gardner, D. (2007). Factors effecting employee use of work-life balance initiatives. New Zealand Journal of Psychology, 36(1), 3-12. 
Solnet, D., Krali, A., \& Kandampully, J. (2012). Generation Y employees: An examination of work attitude differences. Journal of Applied Management and Entrepreneurship, 17(3), 36-54.

Tessema, M., \& Soeters, J. (2006). Challenges and prospects of HRM in developing countries: Testing the HRM performance in Eritrean service. International Journal of Human Resource Management, 17(1), 86-105.

Thwala, D. W., Ajagbe, A. M., Enegbuma, W. I., Bilau, A. A., \& Long, C. S. (2012). Sudanese small and medium sized construction firms: An empirical survey of job turnover. Journal of Basic Applied Scientific Research, 2(8), 7414-7420.

Torrington, D., Hall, L., \& Taylor, S. (2008). Human Resource Management (7th ed.). Harlow: Prentice Hall.

Uddin, M., Das, A., \& Rahman, M. (2008). Promoting tourism industry: A Bangladesh Perspective. The Chittagong University Journal of Business Administration, 23, 247-265.

US Bureau of Labor Statistics. (2018). Bureau of Labor Statistics. Retrieved August 10, 2019, from https://www.bls.gov/opub/mlr/2018/

Werther, W., \& Davis, K. (2002). Personnel Management and Human Resources. New York: McGraw-Hill.

White, M., Hill, S., McGovern, P., Mills , C., \& Smearton, D. (2003). High performance management practices, working hours and work-life balance. British Journal of Industrial Relations, 41, 175-195. 